\title{
Law, Law-Books and Tradition in Early Medieval Ireland
}

\author{
Fangzhe Qiu
}

The richness of medieval Irish law texts can be appreciated from multiple perspectives. ${ }^{1}$ As regulations of behaviors they cover a dazzling array of topics in such detail, that historians are able to reconstruct many aspects of medieval Irish society from them. From a linguistic angle, the strata of compositions in law texts traverse a millennium from the seventh to the seventeenth century, and thus afford valuable witnesses to the development of the Irish language. The law texts refer freely to history, literature, medical theories and religious texts, sometimes even bearing unique testimony to texts that are otherwise lost. The late medieval manuscripts that record law texts are no less a kaleidoscope of learning, with texts on many other subjects copied side by side with law tracts.

How, and why, does the study of law seamlessly merge with those of other subjects, both in the selection of texts in manuscripts and in the law texts themselves? This article aims to demonstrate the organic connection between law texts and the medieval Irish learned tradition as a whole, called senchas ${ }^{2}$ in Old Irish. This article firstly provides a general account of early Irish law, and secondly examines the discourses and techniques employed in early Irish law texts and law-books that creates intertextuality with other branches of senchas. The term "intertextuality" here denotes more than a collective description of the sharing, exchange and interdependence of words, figures, themes, storyplots and temporal-local settings between texts. It is a conscious construction, laden with the ideology of medieval European textual culture, and can be described, in the words of Neil Wright, as "the way in which early medieval writ-

1 This paper is derived from the author's unpublished PhD thesis: Fangzhe Qiu, "Narratives in Early Irish Law Tracts" (PhD thesis, University College Cork, 2015). The author wants to express gratitude to the editor for his invitation to contribute to the book, as well as to Prof. John Carey, Prof. Liam Breatnach and Dr. Kevin Murray who read earlier drafts of this work and gave many insightful comments.

2 Francis John Byrne, "Senchas: The Nature of Gaelic Historical Tradition," Historical Studies 9 (1974): 138, 15 o. 
ers' medium and message could be informed by and interact with other texts which they had read, text which would, for the most part, also have been familiar to their audience."3 It is argued, that such intense intertextuality between all branches of the learned tradition established the authority of the law texts in the lack of direct royal legislation and enforcement, and at the same time continuously renewed the tradition in a dynamic process.

Ireland had never been part of the Roman Empire, and Roman Law left little influence on the vernacular Irish law of the Early Middle Ages. ${ }^{4}$ Some institutions of early medieval Irish laws may have been in existence long before the first law-books in Ireland were even written. ${ }^{5}$ However, judging from linguistic evidence and historical references, vernacular law texts were first written down in Ireland in the seventh and the eighth centuries in Old Irish, ${ }^{6}$ using the Roman alphabet and an orthography that is based on a form of Latin used in Britain and brought to Ireland by British missionaries around the fifth century. ${ }^{7}$ The seventh and eighth centuries witness an explosion in vernacular text production in Ireland, when a large number of legal, genealogical, homiletic and narrative texts were committed to letters. Among these are two substantial legal compilations. The first is called Senchas Már [Great tradition], which consists of 47 independent tracts, according to the extant evidence. ${ }^{8}$ It was probably compiled in the north of Ireland under the aegis of the religious center of Armagh in the latter half of the seventh century. ${ }^{9}$ The second was in all

3 Neil Wright, History and Literature in Late Antiquity and the Early Medieval West: Studies in Intertextuality (Aldershot: Ashgate Publishing Limited, 1995), vii. See also Rolf H. Bremmer Jr, "More than Language: Law and Textual Communities in Medieval Frisia," Chapter 4 in this volume.

4 Thomas M. Charles-Edwards, The Early Mediaeval Gaelic Lawyer, Asnc Publications 4 (Cambridge: Cambridge University Press, 1999), 3-5.

5 Fergus Kelly, A Guide to Early Irish Law (Dublin: Dublin Institute for Advanced Studies, 1988), 231-32.

6 Liam Breatnach, A Companion to the Corpus Iuris Hibernici, Early Irish Law Series 5 (Dublin: Dublin Institute for Advanced Studies, 2005), 354-55; Pamela O'Neill, "Unravelling Time in Early Irish Law," in Language and Power in the Celtic World:Papers from the Seventh Australian Conference of Celtic Studies, University of Sydney, September 2010, ed. Anders Ahlqvist and Pamela O'Neill (Sydney: University of Sydney, 2011).

7 Paul Russell, "'What was Best of Every Language': The Early History of the Irish Language," in Prehistoric and Early Ireland, ed. Dáibhí Ó Cróinín, New history of Ireland 1 (Oxford: Oxford University Press, 2005), 415-18.

8 Liam Breatnach, “On the Original Extent of the 'Senchas Már', Ériu 47 (1996): 1-43; Neil McLeod, "A True Companion to the Corpus Iuris Hibernici [Review of: Liam Breatnach, A Companion to the Corpus Iuris Hibernici, Early Irish Law Series 5 (Dublin, 2005)]," Peritia 19 (2005): $136-63$.

9 Liam Breatnach, The Early Irish Law Text Senchas Már and The Question of Its Date, E.C. Quig- 
likelihood composed in Munster, in the southwest of Ireland, between 712 and 742 judging from internal references. ${ }^{10}$ It has two constituent texts, titled Bretha Nemed Toisech [The first judgments of the privileged classes] and Bretha Nemed Dédenach [The last judgments of the privileged classes] respectively, and as a whole is commonly known as the Bretha Nemed [Judgments of the privileged classes]. Besides these two compilations, there are more than twenty Old Irish law tracts that survive in full or in fragments, and some others that leave only hints of their existence. ${ }^{11}$ The Old Irish law tracts thus constitute a large corpus that surpasses any other Western European vernacular legal tradition in terms of size and variety, and the repercussions of this rush of textualization were lasting and profound: it seems that all aspects of the legal system had been given textual expression by that time, so that no major law tract was produced after the ninth century; and whatever form the law might have had in its pre-written life, it was thereafter fixed and more or less faithfully transmitted for the next millennium.

The vernacular Irish law tracts are quite distinct in several aspects from the Germanic law-codes on the continent and in England. The majority of early Irish law tracts are not promulgated codes made by royal legislature, but lawbooks composed and copied by the jurists of mixed legal, poetic and ecclesiastical backgrounds, and thus their authority and currency rely on the guardianship of a learned class. ${ }^{12}$ They not only cover remedy and penalty for offences but also actively construct and regulate all aspects of social life, ranging from the binding of clientship, marriage arrangements, dissolution of contracts, and allocation of mill-usage, to the keeping of bees and the story repertoire of a poetic scholar. The individual tracts do not always agree with each other on the same subject matter which may reflect regional differences, ${ }^{13}$ changes over

gin Memorial Lectures 13 (Cambridge: Department of Anglo-Saxon, Norse, and Celtic, University of Cambridge, 2011).

10 Liam Breatnach, "Canon Law and Secular Law in Early Ireland: The Significance of Bretha Nemed," Peritia 3 (1984): 439-59.

11 See a list of extant legal tracts in Kelly, Guide to Early Irish Law, 264-83, and Breatnach, Corpus Iuris Hibernici, chap. 5 .

12 Liam Breatnach, "Lawyers in Early Ireland," in Brehons, Serjeants and Attorneys: Studies in the History of the Irish Legal Profession, ed. Daire Hogan and W.N. Osborough (Dublin: Irish Academic Press, 1990); Charles-Edwards, Early Mediaeval Gaelic Lawyer, 8-9. Compare this to the situation in Wales where the law texts were compiled as one code of law under the supervision of the royal court and its officials, see the contribution by Sarah Elin Roberts, “'A Rather Laborious and Harassing Occupation': The Creation of the Ancient Laws and Institutes of Wales," Chapter 15 in this volume. 
time ${ }^{14}$ or merely divergent opinions among the jurists..$^{15}$ Moreover, early Irish law seldom relies on a centralized authority to adjudicate or to enforce the judgment; although the king presides over the cases, either as the judge or as a supporting dignitary, if the cases are submitted to him. ${ }^{16}$ Rather, the judicial function is shared between the judges, the lords, the poetic scholars and the clergy, while disputes are settled, and judgments are enforced, mostly by means of a highly sophisticated system of pledges, sureties, and witnesses. ${ }^{17}$ This lack of centralized authority in law mirrors the reality of early medieval Ireland as a politically fragmented, rural society, locally controlled by petty kings and kin groups.

Promulgated laws indeed existed in early medieval Ireland. These include two types, namely rechtgae [edict; pl. rechtgai] and cáin [penal regulation; pl. cánai], though there are a few non-promulgated law texts that also bear the title of cáin. Cánai were jointly promulgated and sponsored by royal and ecclesiastical powers to assert their authority, while rechtgai mostly arose in response to special conditions such as invasion or famine. ${ }^{18}$ They seem to have needed to be renewed or reissued after a certain period..$^{19}$ The most famous promulgated law is the cáin of Adomnán, which was promulgated in 697 to protect non-combatants, such as the clergy, children and women..$^{20}$ Ecclesi-

International Conference on the Ulster Cycle of Tales, ed. Mícheál Ó Mainnín and Gregory Toner (Dublin: Four Courts Press, 2017), 19-22.

14 e.g., Daniel A. Binchy, ed., Críth Gablach (Dublin: Dublin Institute for Advanced Studies, 1941), 2, ll. 47-51.

15 Neil McLeod, "Di Ércib Fola," Ériu 52 (2002): 123-216.

16 See Marilyn Gerriets, "The King as Judge in Early Ireland," Celtica 20 (1988): 29-52 and the description of the seating of court in Fergus Kelly, "An Old-Irish Text on Court Procedure," Peritia 5 (1986): 74-106.

17 A good but brief introduction to the various procedures and sureties in Irish law can be found in Richard Sharpe, "Dispute Settlement in Medieval Ireland: A Preliminary Inquiry," in The Settlement of Disputes in Early Medieval Europe, ed. Wendy Davies and Paul Fouracre (Cambridge: Cambridge University Press, 1986). The law tract Cóic Conara Fuigill [Five Paths of Litigation], which details a wide range of procedures used in binding contracts and litigations, has been edited and translated in Christophe Archan, Les Chemins du Jugement. Procédure et Science du Droit dans l'Irlande Médiévale, Romanité et Modernité du Droit (Paris: De Boccard, 2007).

18 Charles-Edwards, Early Mediaeval Gaelic Lawyer, 52-61.

19 Julianna Grigg, "Aspects of the Cáin: Adomnán's Lex Innocentium," Journal of the Australian Early Medieval Association 1 (2005): 41-50; Neil McLeod, "Cáin Adomnáin and the Lombards," in Language and Power in the Celtic World, ed. Anders Ahlqvist and Pamela O'Neill (Sydney: University of Sydney, 2011).

20 Kuno Meyer, ed., Cáin Adamnáin: An Old Irish Treatise on the Law of Adamnan (Oxford: 
astical legislations, including canon laws and penitentials, are abundant and influential, culminating in the late-seventh or early-eighth century Collectio Canonum Hibernensis [The Irish collection of canons] which is the earliest systematic canon law collection in Europe..$^{21}$ The ecclesiastical laws and the customary laws are interlinked: some Old Irish law tracts, such as Córus Bésgnai [The ordering of discipline] ${ }^{22}$ or Bretha Nemed, derive their contents from the Scriptures or the canons, ${ }^{23}$ while the Collectio Canonum Hibernensis makes references to secular legal concepts. ${ }^{24}$

Law tracts compiled in the Old Irish period have been subject to centuries of copying, glossing, accretion and redaction. The outcome is an accumulated body of annotated law texts consisting of diverse chronological layers. The term commonly used for the portion of the original Old Irish law tracts is "canonical texts"; words or sentences of the canonical texts are annotated by "glosses"; and continuous sections, or the subject matter as a whole, are discussed independently of the immediate wording of the canonical text in "commentaries". The commentaries are not tied to specific words and can remark on various topics at the same time; therefore, they are often collected from various sources to form a body of explications to early Irish law. A thematically organized collection of extracts from canonical tracts accompanied by commentaries forms a "digest." 25 The earliest glosses seem to have been made in the Old Irish period, not long after the compilation of the canonical texts themselves, ${ }^{26}$ but throughout the Middle Ages and Early Modern period, fresh glosses and commentaries kept being furnished to the canonical texts. Therefore, the mise-en-page of a legal manuscript page varies from running canonical text with interlinear glosses in smaller script to long paragraphs of digests

Oxford Clarendon Press, 19०5); Pádraig Ó Néill and David Dumville, eds., Cáin Adomnáin and Canones Adomnani (Cambridge: Department of Anglo-Saxon, Norse, and Celtic, University of Cambridge, 2003).

21 Hermann Wasserschleben, ed., Die irische Kanonensammlung (Giessen: J. Rickersche Buchhandlung, 1874). Roy Flechner, ed., The Hibernensis, 2 vols. (Washington, D. C.: Catholic University of America Press, 2019).

22 Liam Breatnach, ed., Córus Bésgnai: An Old Irish Law Tract on the Church and Society, Early Irish Law Series 7 (Dublin: Dublin Institute for Advanced Studies, 2017).

23 Breatnach, "Canon Law".

24 Donnchadh Ó Corráin, Liam Breatnach, and Aidan Breen, "The Laws of the Irish," Peritia $3(1984): 382-438$.

25 For a fuller description of the types of combination of textual layers see: Fergus Kelly, "Texts and Transmissions: The Law-Texts," in Irland und Europa im früheren Mittelalteren: Texte und Überlieferung, ed. Próinséas Ní Chatháin and Michael Richter (Dublin: Four Courts Press, 2002); Breatnach, Corpus Iuris Hibernici, 92-99.

26 Breatnach, Corpus Iuris Hibernici, 338-46. 
interspersed with occasional quotations of canonical texts which are formally undistinguishable from the digests. ${ }^{27}$

All texts of Old Irish customary law survive only in manuscripts from the Late Middle Ages. The earliest manuscript that records vernacular Irish law texts is the twelfth-century Oxford, Bodleian Library, Ms Rawlinson B 502 which, however, is predominantly non-legal in content and includes only two law tracts. ${ }^{28}$ The majority of manuscripts which contain a substantial portion of legal materials were written between the fourteenth and the seventeenth century by scribes from the late medieval learned legal families, such as the Mac Aodhagáin who quickly emerged on the stage in the fourteenth century. ${ }^{29}$ None of the manuscripts is purely legal in content: poetic, ${ }^{30}$ medical, ${ }^{31}$ historical and grammatical texts are copied side by side with law texts in the same manuscript. These manuscripts also present later compositions that are evidently designed as instructional materials in the form of pedagogical verse ${ }^{32}$ or moot pleading, ${ }^{33}$ which indicates the primary function of the law-books as manuals for private study. Each law-book fossilizes a moment in the fluid scholastic tradition, ${ }^{34}$ while representing a textual unity in grammatical and legal discourse. ${ }^{35}$

The mixture of a broad array of genres in manuscripts that contain law tracts is mirrored at an intra-textual level. Modern scholars identify certain early Irish texts as "law tracts" as they describe rules that govern behaviour within society,

27 Kelly, Guide to Early Irish Law, 225-31.

28 Brian Ó Cuív, Catalogue of Irish Language Manuscripts in the Bodleian Library at Oxford and Oxford College Libraries, 2 vols. (Dublin: Dublin Institute for Advanced Studies, 2001), 1:163-201.

29 Katharine Simms, "The Brehons of Later Medieval Ireland," in Brehons, Serjeants and Attorneys: Studies in the History of the Irish Legal Profession, ed. Daire Hogan and William Osborough (Dublin: Irish Academic Press, 199o).

30 e.g. Fangzhe Qiu, "Manuscript Contexts of Early Irish Law Tracts: A Case Study on Uraicecht Becc," Proceedings of the Harvard Celtic Colloquium 35 (2015): 150-71.

31 e.g., Daniel A. Binchy, "Bretha Crólige," Ériu 12 (1938): 1-77; Daniel A. Binchy, "Bretha Déin Chécht," Ériu 20 (1966): 1-66.

32 e.g., Máirín Ní Dhonnchadha, "An Address to a Student of Law," in Sages, Saints and Storytellers: Celtic Studies in Honour of Professor James Carney, ed. Donnchadh Ó Corráin, Liam Breatnach, and Kim McCone (Maynooth: An Sagart, 1989).

33 e.g., Daniel A. Binchy, ed., Corpus Iuris Hibernici, 6 vols. (Dublin: Dublin Institute for Advanced Studies, 1978), 6:2204.1-2208.19.

34 Katharine Simms, "Charles Lynegar, the O Luinín family and the Study of Seanchas," in $A$ Miracle of Learning: Studies in Manuscripts and Irish Learning: Essays in Honour of William O’Sullivan, ed. Toby C. Barnard and Dáibhí Ó Cróinín (Aldershot: Ashgate Publishing Limited, 1998).

35 Martin Irvine, The Making of Textual Culture: "Grammatica" and Literary Theory, 350-1100 (Cambridge: Cambridge University Press, 1994), 390-91. 
yet these texts are never totally legal or even regulatory in nature. Some law tracts are embedded in narratives or arcane poems. ${ }^{36}$ Words in law texts are often subject to grammatical and exegetical analysis, and exemplified by verses and stories from the literary tradition, while saints' lives and place-name lore are adapted to explain the origins of the law tracts. ${ }^{37}$ These extra-legal contents can be found in all layers of the law texts; in other words, they are not merely products of inquisitive glossators, but also part of the original composition in the Early Middle Ages.

The fuzzy display of discourses and contents in early Irish law texts and manuscripts stands in stark contrast to most modern laws and poses difficulty for modern editors who wish to cherry-pick the "purely legal" content. However, such variety is the quintessential characteristic of medieval Irish legal writing. The following analysis tries to reveal the form and reason of such variety in unity, by examining the discourses used in early Irish law texts and the way they bridge contents from diverse branches of learning.

In terms of mode of discourse, three types can be found in early Irish law texts, namely, provision, narration and exposition. In comparison, most modern law texts consist solely of provisions, which are either apodictic, making unconditional statements, or casuistic, comprising a hypothetical protasis of condition and an apodosis of legal consequence. These two types are also predominant in the provisions of early Irish law. For example ni bi sena iar naititiu [let there not be denial after recognition of right] (apodictic) ${ }^{38}$ and mas asa laim docuaid, is amail cetsceinm [if it is out of his hand that it (the anvil) has come, it is regarded as the first springing] (casuistic). ${ }^{39}$ In the Irish tradition provisions are characteristic of, but not confined to, law texts in the strict sense. Texts laying out the rights and duties of tribes and kings, such as Lebor na Cert [The Book of Rights $]^{40}$ and "A Poem on the Airgíalla,"41 include a large num-

36 For examples see the "Saga of Fergus mac Léti": Binchy, Corpus Iuris Hibernici, 2:352.26356.38, 3:881.4-883.36, 5:1663.20-1666.28, edited in Daniel A. Binchy, "The Saga of Fergus Mac Léti," Ériu 16 (1952): 33-48; Daniel A. Binchy, “An Archaic Legal Poem," Celtica 9 (1971): $15^{2-68 .}$

37 e.g., Fangzhe Qiu, "Wandering Cows and Obscure Words: a Rimeless Poem from Legal Manuscripts and Beyond," Studia Celtica Fennica 1o (2013): 90-111; Paul Russell, "Laws, Glossaries and Legal Glossaries in Early Ireland," Zeitschrift für celtische Philologie $5_{1}$ (1999): $85^{-115}$.

38 Binchy, Corpus Iuris Hibernici, 4:1361.27.

39 Binchy, Corpus Iuris Hibernici, 2:267.21.

$40 \quad$ Myles Dillon, ed., Lebor na Cert: The Book of Rights, Irish Texts Society 46 (London: Irish Texts Society, 1962).

41 Máirín O Daly, “A Poem on the Airgialla," Ériu 16 (1952): 179-88. 
ber of provisions, but these are seldom regarded as laws but rather as historical documents like charters, because the undertakers of duties and rights in them are usually specific holders of titles or tribes. Penitentials and wisdom texts, the compilation of which was closely related to the production of secular law texts, ${ }^{42}$ contain provisions or didactic injunctions that are similar to provisions; and the geis [prohibition, injunction] in early Irish literature, imposed on kings and heroes to avoid or perform certain ritualized deeds, generally takes the form of provision and has a social and cosmological dimension. ${ }^{43}$ This typically legal discourse provides intertextuality between law and different types of texts. Such continuum in discourse between law texts and other branches of senchas, however, is even better attested in the other two modes of discourse, namely narration and exposition.

The abundance of narratives in early Irish law texts may strike not only modern jurists, but also their medieval counterparts outside Ireland, as outlandish. So far more than 110 narratives have been identified, ${ }^{44}$ in the most extensive current edition of early Irish law texts, the six-volume Corpus Iuris Hibernici. ${ }^{45}$ These range from terse passages sketching the skeleton of incidents, ${ }^{46}$ to fulllength sagas embellished with ornate verses; ${ }^{47}$ from accounts of the mythical past ${ }^{48}$ to those of contemporary affairs; ${ }^{49}$ from the exodus and Christ's Passion, ${ }^{50}$ to conversation of countrymen.${ }^{51}$ They appear in almost every possible

42 Marilyn Gerriets, "Theft, Penitentials and the Compilation of the Early Irish Laws," Celtica 22 (1991): 18-32. Fergus Kelly, ed., Audacht Morainn (Dublin: Dublin Institute for Advanced Studies, 1976), xviii-xix.

43 Thomas M. Charles-Edwards, “Geis, Prophecy, Omen, and Oath," Celtica 23 (1999): 38-59; Tom Sjöblom, "Before Geis Became Magical: A Study of the Evolution of an Early Irish Religious Concept," Studia Celtica 32 (1998): 85-94.

44 For a preliminary list of these narratives see Fangzhe Qiu, "Narratives in Early Irish Law: A Typological Study," in Medieval Irish Law: Texts and Contexts, ed. Anders Ahlqvist and Pamela O'Neill (Sydney: University of Sydney, 2013).

45 Binchy, Corpus Iuris Hibernici.

46 e.g. the reference to John 8.7 in a commentary, Binchy, Corpus Iuris Hibernici, 3:847.8-11, 5:1924.1-9.

47 e.g. the "Saga of Fergus mac Léti", Binchy, "Saga of Fergus Mac Léti,".

48 e.g. the narrative concerning the first battle ever fought in Ireland, Binchy, Corpus Iuris Hibernici, 2:380.1-13, 5:1686.28-1687.3.

49 e.g. an anecdote attributing the Papal Bull Laudabiliter which purported to grant Henry II the right over Ireland to the offence of some local churls, Binchy, Corpus Iuris Hibernici, 6:1950.18-23.

$5^{\circ}$ e.g. a discussion of Longinus's piercing of Christ in Binchy, Corpus Iuris Hibernici, 4:1305 .34-37.

$5^{1}$ e.g. a passage that claims to record the poetic dialogue of two Connacht men, Binchy, Cor- 
location: some serve as introduction to a law tract, some in the annotations, and some even as part of the canonical text itself. No modern or medieval Western European legal tradition uses narratives in such an extensive and systematic manner, perhaps apart from the Aggadic halakhah materials in the rabbinic tradition. ${ }^{52}$ These materials may afford some comparison to the Irish legal narratives in terms of number and variety, but much further research is needed to reveal whether there are more similarities between the two apart from superficial resemblance. Yet it will seem less exotic if one keeps in mind that narration is the primary discourse of senchas: much of early Irish literature, historiography, onomastic lore and hagiography is written in prose or verse narrative. In stark contrast to the timeless, universal provision, narration is inherently temporal and individual, and thus particularly suitable for documenting cultural memory. When narration is employed in law texts, it affirms that the law texts are not merely collections of norms, but also the product and memory of the longue durée of Irish history. Moreover, narration in law texts is not isolated from the writing practice in other types of texts. Narratives originating outside the law lost none of their style and appeal when adopted into legal contexts; and many narratives of legal origin relate their stories so skillfully and dramatically that they can claim to be literature in every sense of the word. Rhetorical devices employed by literary works are ubiquitous in the legal narratives, such as the "narrative openers" identified by Proinsias Mac Cana, ${ }^{53}$ or the use of prosimetrum to carry out various textual functions. ${ }^{54}$ Narratives appear at the same nodal points in law texts as in genealogy, glossaries and the place-name lore (dindsenchas): they arise in response to questions of origin, supply contextual information, or exemplify concepts and words..$^{55}$

While the mode of narration renders possible the formal assimilation of law texts to other branches of the senchas, the contents of legal narratives construct temporal-personal relationships that are shared by non-legal narratives, and thereby locate the composition of the law tracts or the origin of the rules

pus Iuris Hibernici, 6:2112.36-39, edited in Calvert Watkins, ed., "Varia III," Ériu 29 (1978): $155^{-6}$.

$5^{2}$ Moshe Simon-Shoshan, Stories of the Law: Narrative Discourse and the Construction of Authority in the Mishnah (New York: Oxford University Press, 2012).

53 Proinsias Mac Cana, "Narrative Openers and Progress Markers in Irish," in A Celtic Florilegium: Studies in Memory of Brendan O Hehir, ed. Kathryn A. Clar, Eve E. Sweetser, and Claire Thomas (Lawrence, MA: Celtic Studies Publications, 1996).

54 For typological studies see Proinsias Mac Cana, "Notes on the Combination of Prose and Verse in Early Irish Narrative," in Early Irish Literature: Media and Communication, ed. Stephen N. Tranter and Hildegard L.C. Tristram (Tübingen: Narr, 1989).

Qiu, "Narratives in Early Irish law," 116-22. 
in the time-space in the collective memory. A few legal narratives have direct textual precedents outside of the law tracts, ${ }^{56}$ while some others provided for the texts or stories in sagas and bardic poetry. ${ }^{57}$ Many legal narratives, however, do not have exact counterpart outside the law tracts, but they derive their story plots and dramatis personae from non-legal texts. No fewer than fortyfive legal narratives, for instance, adopt the narrative universe of the Ulster Cycle, which is a large corpus of sagas that center on the martial activities of the ancient Ulster heroes. ${ }^{58}$ A legal commentary ${ }^{59}$ exemplifies the concept of lúaithrind [quick engraving] with a pattern received from a supernatural figure and engraved on Cú Chulainn's shield when he returns from his martial training in Britain. Upon reading this, medieval Irish readers would certainly recall the fearsome combats wrought by this hero, and luaithrind would have been recognized as a prime craft that conveys (supernatural) valor to the shieldbearer. This connection further substantiates the main point of the law text commented on, namely that a wright must be able to perform lúaithrinde lúathluth [swift movement of quick engraving] to achieve a privileged status. ${ }^{60}$ Such intertextual cohesion between the legal narrative and the Ulster Cycle stories thus invokes rich cross-references and places the law tracts into a cultural and historical coordinate grid.

However, it is worth bearing in mind the nature of senchas as a collective memory. Gregory Toner has argued that it is precarious to impose modern conceptions of "history" on the medieval art of handling the past. ${ }^{61}$ Despite that the contents of senchas are overwhelmingly presented as knowledge from the past or about the past, senchas's accounts of the past do not guarantee historicity as we understand the concept today, as senchas is primarily a textual tradition, and is concerned with textual authority, rather than with empirical

56 e.g., Binchy, Corpus Iuris Hibernici, 1:250.1-32, quoting from the Dindsenchas of Achall, Edward John Gwynn, ed., The Metrical Dindshenchas, 5 vols. (Dublin: Hodges \& Figgis, 1935; repr., Dublin: Dublin Institute for Advanced Studies, 1991), 1:46.

57 e.g., Binchy, Corpus Iuris Hibernici, 6:2230.1-2, 2232.33-37 was copied into the saga Scéla Mosauluim [The Tidings of Moṡaulum], in Máirín O Daly, ed., Cath Maige Mucrama: the Battle of Mag Mucrama, Irish Texts Society 5o (London: Irish Texts Society, 1975), 76-77.

$5^{8}$ Qiu, "Ulster Cycle in the Law Tracts".

59 Binchy, Corpus Iuris Hibernici, 6:2114.5-24, edited in Myles Dillon, ed. "Stories from the Law-tracts," Ériu 11 (1932): 42-65 (54-55), translated in Richard Irvine Best, "Cuchulainn's Shield," Ériu 5 (1911), 72.

6o Binchy, Corpus Iuris Hibernici, 6:2219.37-38, which also appear in the triads, see Kuno Meyer, The Triads of Ireland, Todd Lecture Series, vol. 13 (Dublin: Hodges \& Figgis, 1906), 16-17.

61 Gregory Toner, “The Ulster Cycle: Historiography or Fiction?" Cambrian Medieval Celtic Studies 40 (Winter 2000): 1-20. 
verity, as remarked by Mary Carruthers, "in considering medieval views of textual authority, one needs always to keep in mind that auctores were, first of all, texts, not people." 62

Two textually related legal narratives which propose to explain the situation of the making of law tracts Cáin Fuithirbe [The regulation of Fuithirbe] and Anfuigell [Wrong judgment?] may serve to show how, even for medieval readers, textual authority is established through intertextual links rather than through historical veracity of the account. Neither of these two tracts survives in full; only snippets from their canonical texts are preserved with extensive glosses and commentaries. Both texts appear to deal with a variety of topics and it is hard to postulate their original extents from the sporadic extracts. ${ }^{63}$

What survives of Cáin Fuithirbe includes a list of names of Munster kings who might have convened to promulgate the law, ${ }^{64}$ which suggests that the time of its composition was during the reign of the King of Munster Finguine mac Cathail Chon-cen-máthair, and more specifically between 678 and $683 .{ }^{65}$ A Middle Irish introductory narrative is appended to Cáin Fuithirbe and reaffirms this date. ${ }^{66}$ Moreover, the Middle Irish narrative claims the author of the law tract to be Amairgen son of Amalgaid from the Déssi, a poet who was dispatched by the people of Munster to learn native law, and returned to compose it on the plain of Fuithirbe, probably the modern Muckross Demesne in Co. Kerry. ${ }^{67}$ So far, a late seventh-century date of composition seems secure, ${ }^{68}$ yet the appealing historical value is certainly "spoiled" by the additional assertion by the Middle Irish narrative that the tract "was afterwards shown to St. Patrick after [his] coming" in the fifth century and was subject to the saint's extensive revision. ${ }^{69}$

Clearly, historicity was not the concern here, as the fifth-century saint could not have any knowledge of a composition made in the seventh century. The medieval authors' purpose was rather to link their texts with significant moments in the senchas, and in this case the moment is no other than St.

62 Mary Carruthers, The Book of Memory: A Study of Memory in Medieval Culture (Cambridge: Cambridge University Press, 1990), 190.

63 Breatnach, Corpus Iuris Hibernici, 165, 215-16.

64 Binchy, Corpus Iuris Hibernici, 5:1554.1-19.

65 Daniel A. Binchy, "The Date and Provenance of Uraicecht Becc," Ériu 18 (1958):52-54; Liam Breatnach, "The Ecclesiastical Element in the Old-Irish Legal Tract Cáin Fhuithirbe," Peritia 5 (1986): $36-52$.

66 Binchy, Corpus Iuris Hibernici, 2:687.37-688.20.

67 Seán Ó Coileáin, "Mag Fuithirbe Revisited," Éigse 23 (1989): 26.

68 But see Ó Coileáin's caveat in "Mag Fuithirbe".

69 Binchy, "Uraicecht Becc," 52. 
Patrick's censuring of the pagan laws of the Irish to ensure that they conform to Christian doctrines, a legend pervasively invoked in Senchas Már to explain the origin of that collection, especially in the "Pseudo-historical prologue to Senchas Már", a possibly ninth-century narrative prefixed to some copies of Senchas Már tracts. ${ }^{70}$ Though Cáin Fuithirbe does not belong to that collection, it is deliberately linked to Senchas Már not only by employing the Patrician legend, but perhaps also by stating that the knowledge needed to compose this tract was obtained by learning outside of Munster. In the related prologue of Anfuigell, it is more explicitly pointed out that the learning necessary for composing the tract was acquired in "the North", where Senchas Már was compiled. ${ }^{71}$

Cáin Fuithirbe was promulgated by a number of minor kings in the late seventh century, but it portrays itself as part of the heritage from St. Patrick's Christianizing mission, and thus deserves currency throughout the whole of Ireland in the same manner as Senchas Már, ${ }^{72}$ not just to be limited to the province of Munster. Moreover, the Middle Irish narrative also makes reference to the Passion of Christ to support St. Patrick's abrogation of the excessive gentile rules, and addresses the Irishmen as descendants of Míl, thus subscribing to the account regarding the origin of the Irish nation as invented by contemporary historiographers. ${ }^{73}$ Besides showing erudition in many threads of learning, the prologue effectively provides multiple recognized cultural clues to liaise with the learned tradition and to render itself part of $i{ }^{74}$ and the number and prominence of such cultural clues in a text contains are far more important than their harmonious organization.

The Middle Irish introduction to Anfuigell [Wrong Judgement?] ${ }^{75}$ was clearly modelled upon the prologue to Cáin Fuithirbe. It gives Cummaín, who was well trained in Latin learning but did not quite qualify in native law, as the author, perhaps intending Cumméne Fota. Cumméne Fota was a renowned sapiens [sage, scholar], but he died in 662 , more than a decade before the start

70 This legend has been edited and translated in John Carey, ed., "An Edition of the PseudoHistorical Prologue to the Senchas Már," Ériu 45 (1994): 1-32.

71 Binchy, Corpus Iuris Hibernici, 3:979.26.

72 Senchas Már apparently regards itself in effect over the whole island of Ireland, as indicated by the many references in the canonical parts of its constituent texts to "this island," see Breatnach, Early Irish Law Text, 37-39. John Carey, The Irish National Origin-Legend: Synthetic Pseudohistory (Cambridge: Department of Anglo-Saxon, Norse, and Celtic, Cambridge University, 1994).

74 Robin Chapman Stacey, "Law and Literature in Ireland and Wales," in Medieval Celtic Literature and Society, ed. Helen Fulton (Dublin: Four Courts Press, 2005), 75. Binchy, Corpus Iuris Hibernici, 3:979.23-26. 
of the reign of Finguine (678-695) which is claimed in the narrative as the time of composition. ${ }^{76}$ Meanwhile, all other elements are identical to the Cáin Fuithirbe prologue, including the eponymous place-name Mag Fuithirbe. Such identity of time, place and cause in the making of two law tracts is unlikely, and any informed reader in medieval Ireland would not have hesitated to dismiss the historicity of the information in the Anfuigell prologue. Again, what matters to the author of the Anfuigell prologue is becoming part of the tradition, and Anfuigell indeed partakes in the authority of Cáin Fuithirbe by appropriating its narrative, as well as by attributing the authorship to the long deceased Cumméne Fota (if it is really he who is intended): a Munster figure prominent in both secular and ecclesiastical literary contexts.

Personages in legal narratives, even those who indeed lived in the historical period, always appear in connection with certain master narratives as recognized by the senchas. Cenn Fáelad's lineage (of the royal family of Cenél nEógain in the Northern half of Ireland) and his obituary (679) are consistently documented in the genealogies and the annals, ${ }^{77}$ and his fame as a prime scholar (sapiens) and his career in the minor monasteries of Túaim Drecain and Daire Luráin is probably historically authentic. ${ }^{78}$ However, the central theme in the longer narratives about Cenn Fáelad, which are shared by narratives appended to the law tract Bretha Étgid [Judgments of Inadvertence] ${ }^{79}$ and to the grammatical treatise Auraicept na nÉces [Scholars' primer] ${ }^{80}$ and by the longer version of the saga Cath Maige Roth [The battle of Mag Roth] ${ }^{81}$ is that Cenn Fáelad lost his "brain of forgetfulness" in the battle of Mag Roth and was transported to Túaim Drecain for recuperation, where he combined the teaching of three schools. This theme is not present in any annalistic record and is probably a later accretion to the tradition, using Cenn Fáelad as a prototypal learned figure and the three schools as allegory to the components of the Irish intellectualism. ${ }^{82}$ The battle of Mag Roth (637) marked a turn in the politics

\footnotetext{
76 Binchy, "Uraicecht Becc," 52.

77 Seán Mac Airt and Gearóid Mac Niocaill, eds., The Annals of Ulster (to A.D. 1131) Part I, Text and Translation (Dublin: Dublin Institute for Advanced Studies, 1983), s. a. 679.

78 Kim McCone, "Zur Frage der Register im frühen Irischen," in Early Irish Literature: Media and Communication, ed. Stephen N. Tranter and Hildegard L.C. Tristram (Tübingen: Narr, 1989), 66.

79 Binchy, Corpus Iuris Hibernici, 1:250.33-251.3; 3:926.5-18; RIA MS. D v 2, $64^{\text {ra }}$ (edited in Breatnach, Corpus Iuris Hibernici, 381-82).

8o George Calder, Auraicept na n-Éces: The Scholars' Primer (Edinburgh: J. Grant, 1917), 6-7.

81 John O'Donovan, The Banquet of Dun na $n$-Gedh and the Battle of Magh Rath (Dublin: Irish Archaeological Society, 1842), 278-84.

82 Proinsias Mac Cana, "The Three Languages and the Three Laws," Studia Celtica 5 (1970):
} 
of the North of Ireland in the seventh century and forms a key nodal point of the collective memory, ${ }^{83}$ and the prestige of both Auraicept na nÉces and Cath Maige Roth may have helped further propagate the doctrine. ${ }^{84}$ The theme is overtly symbolic, but by the Middle Irish period when the abovementioned narratives were composed, it had acquired a canonical status and later compositions that wished to mention Cenn Fáelad had to subscribe to it.

Such is the weight of this tradition that Bretha Étgid presents it side by side with another narrative as alternative explanations to the origin of the tract. That Middle Irish narrative immediately precedes the Cenn Fáelad story in three copies of the tract, and attributes the composition of Bretha Étgid to Cormac mac Airt, a pre-historic legendary king of Ireland. ${ }^{85}$ It reports that Cormac mac Airt lost an eye in a strife, and therefore forfeited his kingship to his son, to whom Cormac preached Bretha Étgid as an instruction on rightful kingship. Cormac is the central figure in numerous Irish narratives, and has been regarded as the prime example of a just and wise king to whom are attributed wisdom texts, ${ }^{86}$ and stories on ordeals. ${ }^{87}$ Moreover, the strife in which Cormac lost his eye is reported to have led to the expulsion of the Déissi tribes from midland, a legend featuring prominently in the senchas, ${ }^{88}$ more so since the tenth century when the Déissi tribe Dál Cais played a significant role in Irish politics. The canonical text of Bretha Étgid does not mention Cormac mac Airt, but

62-78; McCone, "Register im frühen Irischen," 65; Hildegard L.C. Tristram, "Warum Cenn Faelad sein 'Gehirn des Vergessens' verlor-Wort und Schrift in der älteren irischen Literatur," in Deutsche, Kelten und Iren: 150 Jahre deutsche Keltologie (Hamburg: Buske, 199o) 207-48.

83 Francis John Byrne, Irish Kings and High-kings (Dublin: Four Courts Press, 1987), 113-14.

84 The latter tale is included in the "List A" of the tale-lists compiled in around the tenth century (edited in Proinsias Mac Cana, ed., The Learned Tales of Medieval Ireland (Dublin: Dublin Institute for Advanced Studies, 1980), 43) and presumably was well-known then, see Gregory Toner, "Reconstructing the Earliest Irish Text Tale Lists," Éigse 32 (2000): 88120.

85 Binchy, Corpus Iuris Hibernici, 1:250.1-32; 3:925.1-926.4; RIA MS. D v 2, $64^{\text {ra }}$ (edited in Breatnach, Corpus Iuris Hibernici, 381-82).

86 Narratives concerning Cormac and their significance have been fruitfully explored in Tomás Ó Cathasaigh, The Heroic Biography of Cormac Mac Airt (Dublin: Dublin Institute for Advanced Studies, 1977); see also, Kuno Meyer, ed., Tecosca Cormaic: The Instructions of King Cormac Mac Airt, Todd Lecture Series, vol. 15 (Dublin: Hodges \& Figgis, 19o9).

87 Whitley Stokes, "The Irish Ordeals, Cormac's Adventure in the Land of Promise, and the Decision as to Cormac's Sword," in Irische Texte 3.1, ed. Ernst Windisch and Whitley Stokes (Leipzig: Verlag von S. Hirzel, 1891).

88 e.g., Kuno Meyer, “The Expulsion of the Déssi," Ériu 3 (1907): 135-42; Vernam Hull, "The Later Version of the Expulsion of the Déssi," Zeitschrift für Celtische Philologie 27 (1959): 14-65; Whitley Stokes, "The Annals of Tigernach," Revue Celtique 17 (1896): 19-20. 
many passages of it start with the set formula a maic ara.feiser [O son so that you would find out], and therefore imply a similar, if not the same, backdrop of a royal father preaching his son.

Logically, there cannot be two compositions - one in prehistory, the other in the seventh century — of the same tract. A commentator of Bretha Étgid tried to reconcile this by suggesting that the passages beginning with blai [immunity] and a maic ara.feiser [O son so that you should find out] are authored by Cormac, the others by Cenn Fáelad. ${ }^{89}$ But the canonical text of Bretha Étgid is obviously a unity with blaí, a maic araffeiser and other types of passages interwoven together. Again, these legal narratives betray the efforts of medieval Irish jurists in connecting law texts to as many cultural and historical nodal points as possible: Bretha Étgid is thus both the words of a prehistorical sagacious king, and the study of a seventh-century scholar; it resulted from an offence that foreshadowed the rise of the Dál Cais, and from a battle that consolidated the hegemony of the Uí Néill dynasty over the north of Ireland in the coming centuries. By such connection, law texts join the senchas and in turn reassert the authority of the senchas in a dynamic process. This process, termed "traditionalization" by anthropologists, systematically links texts (and other cultural artifacts) to a conceived meaningful past, a collective memory acknowledged by members of the community as valid guidance for their self-recognition and their lives. ${ }^{90}$ As Tom Mould points out, "the traditional past is evoked not merely as part of a general dialogue with the past, but as part of an attempt to provide authority for one's own narrative performance and interpretation by supporting or contributing to a community's sense of what is 'traditional." ${ }^{1}$

Exposition organizes the provisions and offers critical analyses of their words and meanings, rather than directly stipulating a rule. Expository passages construct a framework in which provisions can be presented, and link general provisions to more detailed ones, or provisions to narratives. Through exposition the provisions are objectified as texts and disposed according to the ideology of grammatica, which embraced all arts and disciplines that were based on texts. ${ }^{92}$ Charles-Edwards has shown that three stylistic features char-

89 Binchy, Corpus Iuris Hibernici, 1:250.16-18.

$90 \quad$ Richard Bauman and Charles Briggs, "Genre, Intertextuality, and Social Power," Journal of Linguistic Anthropology 2 (1992): 131-72; Richard Bauman, "Mediational Performance, Traditionalization, and the Authorization of Discourse," in Verbal Art Across Cultures: The Aesthetics and Proto-aesthetics of Communication, ed. Hubert Knoblauch and Helga Kotthoff (Tübingen: Gunter Narr, 2001).

91 Tom Mould, "The Paradox of Traditionalization: Negotiating the Past in Choctaw Prophetic Discourse," Journal of Folklore Research 42.3 (2005): 257. Irvine, Making of Textual Culture, 6. 
acteristic of Irish legal exposition are rooted in the Latin grammatical culture, namely etymology, enumeration and classroom dialogue..$^{93}$ Enumeration and classroom dialogue are ubiquitous in the law tracts. Apart from the etymological analysis by dissecting word into smaller units, illustrated with instances from Bretha Comaithchesa by Charles-Edwards in the aforementioned article, one finds clear signs of the so called "etymological aetiology" based on the philosophy of Isidore of Seville, ${ }^{94}$ and on the principle of enarratio in medieval grammatica. In the canonical part of the tract Di Chethairsilicht Athgabálae [On the four divisions of distraint], for instance, the period of five-day's stay in the distraint procedure is explained as originating from the name of a woman Cóicthe (literally "of five days" or "the fifth day") who was involved in the first case that demands for such a period. ${ }^{95}$ The judge's name Sen mac Áigi [senior son of fixed period] in the same tract, and the name of the first female-slave in Ireland, Mugdorn ingen Moga [slave-fist daughter of male-slave] in a narrative found in Bretha im Fuillemu Gell [Judgments on the interests of pledges], are also manifest examples of this type.

There are more terms and techniques for which the Irish legal expositions are indebted to the grammatica tradition. Eight introductions prefixed to law tracts employ the accessus ad auctores schema to provide an introductory summary of the making of the tract. ${ }^{96}$ The supplement of an accessus before an authoritative text as an introduction is a salient feature in the medieval grammatica tradition and can be traced to the influence of Aelius Donatus, a late antique grammarian. Donatus made extensive use of Suetonius's lost work, and incorporated a vita of Vergil which precedes his partly lost commentary

93 Thomas M. Charles-Edwards, "Review Article: The Corpus Iuris Hibernici," Studia Hibernica 20 (1980): 147 .

94 Rolf Baumgarten, "Etymological Aetiology in Irish Tradition," Ériu 41 (1990): 115-22; Rolf Baumgarten, "Creative Medieval Etymology and Irish Hagiography (Lasair, Columba, Senán)," Ériu 54 (2004): 49-78.

95 Binchy, Corpus Iuris Hibernici, 2:406.26-407.26.

96 1) Binchy, Corpus Iuris Hibernici, 1:250.1-32 (Bretha Étgid) and a copy in Binchy, Corpus Iuris Hibernici, 3:925.1-926.4; 2) Binchy, Corpus Iuris Hibernici, 1:250.32-35 (Bretha Étgid) and a copy in Binchy, Corpus Iuris Hibernici, 3:926.5-18; 3) Binchy, Corpus Iuris Hibernici, 6:2186.37-38 (Córus Iubaile [The Ordering of Limitation Periods]; 4) Binchy, Corpus Iuris Hibernici, 2:1-342.21 (Pseudo-historical Prologue to Senchas Már) and four copies; 4) Binchy, Corpus Iuris Hibernici, 2:87.37-688.20 (Cáin Fuithirbe); 5) Binchy, Corpus Iuris Hibernici, 6:2143.41 (Fothae Becc [Small Foundation]; 6) Binchy, Corpus Iuris Hibernici, 3:979.23-26 (Anfuigell); 7) Binchy, Corpus Iuris Hibernici, 3:1027.21-1028.12 (Cóic Conara Fuigill [Five Paths of Litigation]) and a copy in Binchy, Corpus Iuris Hibernici, 4:1280.1-21; 8) Binchy, Corpus Iuris Hibernici, 4:1338.5-1341.7 (Mellbretha [Sport Judgments]). 
to Vergil's works. ${ }^{97}$ An accessus, or a materia or an ingressus as it is called in different disciplines, was regarded since late antiquity as a necessary preliminary before the students could set out on quests for a text's sententia, the deeper, spiritual meaning. ${ }^{98}$ This attitude echoes the fundamental role of grammatica in the formation of a textual culture in the Middle Ages, when aspiring students had to learn first to correctly read the letters and to understand the literal sense (lectio) before any inquiry of interpretation and appreciation (enarratio, emendatio and iudicium) could be undertaken. ${ }^{99}$

There are several types of accessus schema during the Middle Ages, which have been conveniently classified by R.W. Hunt. ${ }^{100}$ The single type that all the Irish law tracts adopt is what Hunt terms "type A": this normally consists of the four topics of locus, tempus, persona and causa scribendi, or rendered into Irish locc [place], aimser [time], persa [person] and tucait scríbindi [reason of writing] or fáth airicc [reason of obtaining] respectively. This type is abbreviated from the septem circumstantiae of the classic rhetoricians, especially in Boethius's De differentiis topicis, ${ }^{101}$ which include tempus, locus et persona, res, causa, qualitas (modus) and facultas (materia). ${ }^{102}$ The schema itself was used by continental theologians of the sixth and seventh century in their commentaries on the Bible, but it was also extended to commentary on literary texts, for instance by Remigius of Auxerre, ${ }^{103}$ and was adopted by the Irish literati, probably through acquaintance with the works of Boethius. The schema occurs not only in Irish exegetic ${ }^{104}$ and grammatical texts such as Auraicept na nÉces [Scholars' Primer], but also in introductory commentaries to hagiography and other compositions about saints (e.g. Amra Coluim Chille [Wonder of St. Columba], ${ }^{105}$ and Félire Óengusso [The Martyrology of Óen-

\footnotetext{
97 Irvine, Making of Textual Culture, 121-24.

98 Alastair Minnis, Medieval Theory of Authorship: Scholastic Literary Attitudes in the Later Middle Ages (London: Scholar Press, 1984), 13-14.

99 Irvine, Making of Textual Culture, 4-5.

100 Richard William Hunt, "The Introductions to the 'Artes' in the Twelfth Century," in Studia Mediaevalia in Honorem Admodum Reverendi Patris Raymundi Josephi Martin Ordinis Praedicatorum s. theologiae magistri LXXUM natalem diem agentis (Bruges: De Tempel, 1948).

101 Minnis, Medieval Theory, 224, n. 53.

102 Hunt, "Artes' in the Twelfth Century," 126, n. 1.

103 Minnis, Medieval Theory, 16-17.

104 Including Hiberno-Latin exegetic works, see Bernhard Bischoff, "Turning Points in the History of Latin Exegesis in the Early Irish Church," trans. Colm O'Grady, in Biblical Studies: The Medieval Irish Contribution, ed. Martin McNamara (Dublin: Irish Biblical Association, 1976), 84-87.

105 Whitley Stokes, “The Bodleian Amra Coluim Chille," Revue Celtique 20 (1899): $36-38$.
} 
gus]), ${ }^{106}$ heroic sagas (e.g. Táin Bó Cúailnge [The Cattle-raid of Cooley] ${ }^{107}$ ) and legal texts. The use of the accessus schema to introduce a text makes the text an object of the standardized reading practice, and the various genres of Irish texts are thus united under the guiding principles of medieval grammatica into an integrated learned tradition.

In addition to the accessus, expository markers derived from the grammatica tradition (and often translated from Latin) ${ }^{108}$ are staple ingredients of Irish law texts, such as.$i$. [= i.e.] and amail [= quasi, as], ${ }^{109}$ cair [= quaere, ask] and ní hansa [not difficult], ${ }^{110}$ cid ara n-eperr [= unde dicitur, why is it called], arailiu [= aliter, otherwise], óndí [= ab eo quod est, from that which is] and their variants, ${ }^{111}$ desimrecht [an example], etc. These markers are frequent in legal texts, but they are also part of a shared textual culture and have been used extensively in other types of Irish texts. Besides, several law texts actually engage in meta-theoretical discussion on grammatica and other arts, or deploy grammatical analytic terms to illustrate their content. For instance, a commentary to the Pseudo-historical Prologue to Senchas Már ${ }^{112}$ tries to explain the order of locc, persa and aimsir used in the accessus from the perspective of biblical cosmology, ${ }_{13}^{13}$ adapted from a prose version of Saltair na Rann [The Psalter of Quatrains], a Middle Irish versified account of the sacred history, thereby connecting the law text with exegesis. What follows that passage ${ }^{114}$ is an interesting description of the twelve winds and their colours. The wind-diagram is rooted in classical geography, and is present in Isidore's Etymologiae; ${ }^{115}$ but

106 Whitley Stokes, The Martyrology of Oengus the Culdee: Félire Óengusso Céli Dé (London: Harrison and Sons, 1905), 2, 8.

107 Robin Flower, "Quidam Scotigena .i. Discipulus Boëthii or Boëthius and the Four Conditions of a Tale," Ériu 8 (1916): 150-54.

108 Donnchadh Ó Corráin, "Creating the Past: The Early Irish Genealogical Tradition," Peritia 12 (1998): 193 .

109 Paul Russell, "Quasi: Bridging the Etymological Gap in Early Irish Glossaries," in A Companion in Linguistics: A Festschrift for Anders Ahlqvist on the Occasion of His Sixtieth Birthday, ed. Bernadette Smelik et al. (Nijmegen: De Keltische Draak, 2005).

110 Rolf Baumgarten, "Discourse Markers in Medieval Irish Texts: Cs̄, Cair, Nī and Similar Features," Ériu 43 (1992): 1-37.

111 Paul Russell, "The Sounds of a Silence: The Growth of Cormac's Glossary," Cambridge Medieval Celtic Studies 15 (Summer 1988): 1-30 (22).

112 Binchy, Corpus Iuris Hibernici, 2:342.40-344.11.

113 Edited in John Carey, ed., "A Tract on the Creation," Éigse 21 (1986): 1-9. Slightly different versions of the beginning of this passage are included in the introduction to Cáin Fuithirbe [The regulation of Fuithirbe], Binchy, Corpus Iuris Hibernici, 2:688.20-29o, and in the Preface to Félire Óengusso [the Martyrology of Óengus], Stokes, Martyrology of Oengus, 2.

114 Binchy, Corpus Iuris Hibernici, 2:343.12-22.

115 Isidore of Seville, Etymologiae, 13.11.2-4, in The Etymologies of Isidore of Seville, ed. Stephen 
the doctrine here is also interwoven with Christian spirituality and indigenous topography. ${ }^{116}$ One needs not be surprised at such a richness of grammatical thoughts and materials in the law, after all, if we are to believe in the statement in the Middle Irish tract Urchuillti Bretheman [Injunction of judges], ${ }^{117}$ that judges are to be learned in the details of Auraicept na nÉces, an instruction manual on grammatical analysis of the Irish language, as well as in law tracts. $^{118}$

The influence of grammatical study is even more salient in the opening part of the law tract Cóic Conara Fuigill [Five paths of judgment], ${ }^{119}$ which enumerates the key grammatical concepts needed for analyzing the parts of the "paths" (conara), such as fid $\urcorner$ deach, reim $\urcorner$ forbaidh, alt $\urcorner$ indsci $\urcorner$ etargairi [letter and foot, declension and accent, syllable and gender and inflection]. ${ }^{120}$ These "seven things according to which Gaelic is measured" are important grammatical tools employed extensively in Auraicept na nÉces. They have already been included in the oldest core of the Auraicept $t^{121}$ and were further elaborated as to their meanings and particularities in the later "Book of Ferchertne", a constituent of the Auraicept as it is found today. ${ }^{122}$ Moreover, according to a Middle Irish tract on verse craft, any student of poetry aspiring to become a fili [poetic scholar] has to master exactly these same elements of language, ${ }^{123}$ as a learned fili is distinguished from a bard by formal education which involves such grammatical training. A copy of the law tract Uraicecht Becc [Small primer], ${ }^{124}$ engages with a prolonged discussion of basic Latin and Irish grammar elements before the canonical law text itself begins; this introductory matter utilizes the

A. Barney, W.J. Lewis, J.A. Beach, and Oliver Berghof (Cambridge: Cambridge University Press, 2006), 275 .

116 John Carey, "Cosmology in Saltair na Rann," Celtica 17 (1985):33-52; Barbara Obrist, "Wind Diagrams and Medieval Cosmology," Speculum 72.1 (1997): 33-84; Alfred K. Siewers, "The Bluest-Greyest-Greenest Eye: Colours of Martyrdom and Colours of the Winds as Iconographic Landscape," Cambrian Medieval Celtic Studies 5o (Winter 2005): 31-66.

117 Binchy, Corpus Iuris Hibernici, 6:2103.20-22.

118 Anders Ahlqvist, "Old Irish Airaiccecht 'Primer, etc.," in Medieval Irish Law: Texts and Contexts, ed. Anders Ahlqvist and Pamela O'Neill (Sydney: University of Sydney, 2013), 233.

119 Binchy, Corpus Iuris Hibernici, 3:1027.25-3.

120 Erich Poppe, "Grammatica, Grammatic, Augustine, and the Táin," in Ildánach Ildírech: A Festschrift for Proinsias Mac Cana, ed. John Carey, John T. Koch, and Pierre-Yves Lambert (Andover: Celtic Studies Publications, 1999), 204.

121 Anders Ahlqvist, The Early Irish Linguist: An Edition of the Canonical Part of the Auraicept na $n$ Éces (Helsinki: Societas Scientiarum Fennica, 1982), 5 o.

122 Calder, Auraicept na n-Éces, $54 \mathrm{ff}$.

123 Rudolf Thurneysen, "Mittelirische Verslehren," in Irische Texte 3.1, ed. Whitley Stokes and Ernst Windisch (Leipzig: Verlag von S. Hirzel, 1891), 6.

124 Binchy, Corpus Iuris Hibernici, 6:2255.1-2256.12. 
triad bunad 7 inne 7 airbert [basis and essence and application] to expose the meaning and usage of words. These three meta-theoretical concepts can again be found among the teachings of the Auraicept na nÉces; ${ }^{125}$ and they have been applied to examination of the word étgid [inadvertence] in Bretha Étgid, ${ }^{126}$ and of the word senchas in the commentary to the Introduction to Senchas Már ${ }^{127}$ as well. Another paradigm of ainm [name], indaithmech [analysis] and érchoilliud [definition] is used in examining the word ferb [word] in a commentary to Di Chethairślicht Athgabálae. ${ }^{128}$

These features are of course not limited to law texts. Scholars have shown the fundamental role of grammatica in the formation of Irish textual tradition, which stretches far beyond the linguistic context. ${ }^{129}$ By participating in the same discursive and interpretative framework with other texts, law texts not only share terms but also freely exchange information and perspectives with other constituents of the senchas: it is little wonder that one finds such a wide spectrum of approaches in law texts, including grammatical, historical, poetic and theological contents, and a similar opulence of legal perspective in literature, historiography and place-name lore. ${ }^{130} \mathrm{Here}$, as in other parts of Western Europe, grammatica provides the protocol for a text to be interpreted and evaluated by other texts, genres and discourses, producing a culture that was explicitly intertextual. ${ }^{131}$ The share of expository mode and grammatica protocol between law and the rest of senchas provides an intertextuality through which law texts are accepted as traditional and authoritative.

The discourse of provision constitutes the skeleton of the law texts and defines them as documents recording the regulatory norms of the society; the discourse of narration provide ample references, both in format and in con-

\footnotetext{
125 Calder, Auraicept na n-Éces, 54-55.

126 Binchy, Corpus Iuris Hibernici, 1:251.4-14; Russell, "Growth of Cormac's Glossary," 23.

127 Binchy, Corpus Iuris Hibernici, 2:344.28-31.

128 Binchy, Corpus Iuris Hibernici, 5:1664.5.

129 Morgan Thomas Davies, "Protocols of Reading in Early Irish Literature: Notes on Some Notes to 'Orgain Denna Ríg' and 'Amra Coluim Cille', Cambrian Medieval Celtic Studies 32 (Winter 1996): 1-24; Erich Poppe, "Latinate Terminology in Auraicept na n-Éces," in History of Linguistics 1996, Volume 1. Traditions in Linguistics Worldwide, ed. David Cram, Andrew Robert Linn and Elke Nowak (Amsterdam:John Benjamins Publishing, 1999); Abigail Burnyeat, "The Early Irish Grammaticus?" Aiste 1 (2007): 181-217.

130 Thomas M. Charles-Edwards, "Honour and Status in Some Irish and Welsh Prose Tales," Ériu 29 (1978): 123-41; Tomás Ó Cathasaigh, Táin Bó Cúailnge and Early Irish Law (Dublin: Faculty of Celtic Studies, University College Dublin, 2005); Christophe Archan, "Les Règles de Droit dans la Prose du Dindshenchas de Rennes," Droit et Cultures 64.2 (2012): 91-113, Arnamagnæan Commission, Dictionary of Old Norse Prose online, http://onp.ku.dk/.

Irvine, Making of Textual Culture, 15 .
} 
tent, for the law texts to be located in the intertextual network of the learned tradition senchas; and the discourse of exposition further create a forum for the law texts and other products of the senchas to converse to each other, and to texts even further afield from the grammatica tradition. By actively participating in such an intertextual dialogue, medieval Irish law texts acquired their traditional and authoritative status and thus remained in effect without promulgation and enforcement by the sovereign.

Despite the gradual eclipse of the power of Gaelic chieftains and the decline in the use of native law in the Late Middle Ages in Ireland, the prestige of early medieval law texts lived on and intertextual links were still being constructed and strengthened: Old Irish texts are still being cited as authority in a court pleading composed perhaps in the sixteenth century, ${ }^{132}$ which may have witnessed the final stage of native Irish legal writing. During the early seventeenth century controversy known as "the Contention of the Bards", bardic poets from all over Ireland were composing verses to support the political and genealogical precedence of each's own patron. One of these poems quotes from the canonical text of the Old Irish law tract Ántechtae [Splendid Appropriateness]. ${ }^{133}$ The part in Ántechtae cited by the bardic poet, ${ }^{134}$ in turn, narrates in rimeless verse the story of Cath Maige Mucrama [The Battle of the Plain of Pig-counting], a prominent tale that relates the defeat of Art, the father of Cormac mac Airt, and the career of Lugaid mac Con. ${ }^{135}$ The bardic poet Lughaidh Ó Cléirigh resorted to the law text, and by inference, to the whole tradition surrounding Cath Maige Mucrama, in order to argue that the Northern kings should take precedence over the Southern kings, because according to Ántechtae and Cath Maige Mucrama, the ancestor of Northern kings, Cormac mac Airt, was entitled to compensation by Ligairne, the murderer of Art in the battle and a Leinster adherent to Lugaid mac Con. The tradition, even at the dimming moment of the seventeenth century immediately before the vanishing of the native learned class, was still lively defining the present by referring to the textual past.

132 Binchy, Corpus Iuris Hibernici, 6:2204.1-2208.19.

133 Lambert McKenna, ed., Iomarbhagh na Bhfileadh: The Contention of the Bards (London: Irish Texts Society, 1920), 88-89.

134 Binchy, Corpus Iuris Hibernici, 4:1244.18-1245.16.

135 O Daly, Cath Maige Mucrama. 